\title{
Human-Nature Interactions in the Owo River Catchment, South-West, Nigeria
}

\author{
Olubunmi Adegun*, Shakirudeen Odunuga, Olalekan Ajayi \\ Department of Geography, University of Lagos, Lagos, Nigeria \\ Email: ^oadegun@unila g.edu.ng, odushak@gmail.com, lincolnajayi@gmail.com
}

How to cite this paper: Adegun, O., Odunuga, S. and Ajayi, O. (2019) $\mathrm{Hu}-$ man-Nature Interactions in the Owo River Catchment, South-West, Nigeria. Journal of Environmental Protection, 10, 130-148. https://doi.org/10.4236/jep.2019.102009

Received: October 24, 2018

Accepted: January 21, 2019

Published: January 24, 2019

Copyright $\odot 2019$ by author(s) and Scientific Research Publishing Inc. This work is licensed under the Creative Commons Attribution International License (CC BY 4.0).

http://creativecommons.org/licenses/by/4.0/

Open Access

\begin{abstract}
This paper examines the interactions and feedbacks between environmental and human variables within the Owo River catchment by analyzing land use change, morphometric dynamics, rainfall stationarity and water quality using statistical approach. The results show that built-up land use grew from 142.92 $\mathrm{km}^{2}(12.20 \%)$ in 1984 to $367.22 \mathrm{~km}^{2}(31.36 \%)$ in 2013 at an average growth rate of $7.73 \mathrm{~km}^{2}$ per annum. Total streams length reduced from $622.24 \mathrm{~km}$ in 1964 to $556 \mathrm{~km}$ in 2010 while stream density reduced from 0.53 in 1964 to 0.47 in 2010. The Mann-Kendall trend test $(p$-value $=0.022)$ indicates rainfall non-stationarity. The river has a low level of pollutant loading while annual water abstraction balances water supply. The human environment interaction has not at present critically affected water supply (quality and quantity) but continuous loss of vegetation poses greater challenges.
\end{abstract}

\section{Keywords}

Rainfall, Land Use, Morphometry, Water Supply and Catchment

\section{Introduction}

Sustainable economic development and growth in the water sector of developing countries are threatened by environmental challenges such as flood events, water scarcity and urbanization. The lack of appropriate reform policies has posed greater stress on water resources management [1]. These challenges are directional trajectory of processes and activities that causes stress. It is driven by the relationship and interactions between human and natural processes [2] of watersheds. The response strains and feedbacks are the various challenges militating against sustainable development of affected watershed.

Putting even greater stress on water resources scarcity is the uncertainty associated with the supply sources (surface and ground water), especially in catch- 
ments where water abstraction/intake is needed in large quantities for multi-purpose uses, including municipal water supply to large cities. More worrisome is that this uncertainty in water supply is brought about by both natural and anthropogenic activities, and at the center are the issues of climate and land use changes that have significantly impacted on the hydrology of catchments whose functionality is to supply water to urban environments. While the impacts of climate change on water resources including water supply have been well documented in the literature [3] [4] [5], the impacts and feedbacks of urban growth and conversion of the sub-urban catchments into built-up with great consequences for urban water supply have not been properly researched and documented.

Additionally, the development of sub-urban catchment that produces water supply to major settlements from its natural/semi-natural system has implications for runoff characteristics and water quality. Thus, continuous understanding of the hydrology, including water quality, morphometry and morphology of such sub-urban catchment, is critical to sustainable urban water supply [6] [7]. In the Lagos Megacity for instance, most of the sub-urban watersheds where water is extracted for municipal supply to the city such as Adiyan, Owo and Lower Ogun are currently undergoing changes in land use/land cover, hydrology, morphometry, and morphology as well as water quality changes. These observed changes can be attributed to both natural and anthropogenic factors. The core anthropogenic factor bringing changes into these sub-urban catchments is urbanization [8] [9] [10].

The changes due to both natural and anthropogenic factors have been observed to have impacts on basin morphometry with great consequences for water resources availability and water quality. Basin physical properties have direct relationships with water resources availability, and consequently, any change in stream properties can translate to reduction or increase in water yield and availability [11] [10]. Also, a high variability of rainfall characteristics (intensity, duration and frequency) is becoming more pronounced within the study area; a condition that is impacting seriously on raw water abstraction at Ishashi Intake [10] from the urban sub-catchments in Lagos. In addition to impacting on water availability, urbanization is also impacting on other hydrological responses of the catchments including runoff, peak flow and water quality, thereby, contributing to the non-stationarity or otherwise of the catchment [10]. However, a number of methods have been employed in studying human-environment interactions. This include the statistical methods [12] [13], and combined Geographic Information Systems and Remote Sensing methods [14] [15] [16].

Going by the observable changes taking place in the Owo River catchment, this paper therefore examines the complex interactions and feedbacks leading to changes in the hydrological and morphological characteristics of the Owo River system [10]. The paper analyses the future ability of this semi-urban watershed to sustain water supply in both qualitative and quantitative terms in the face of cumulative environmental change [10]. Specifically, the paper examines the land 
use land cover and Morpho-dynamic changes of the Owo River catchment to identify the impacts of urbanization (anthropogenic activities) on the catchment. It uses a time series of rainfall over the catchment to analyze rainfall non-stationarity (natural process) to explain the sustainability of water supply in the face of climate change. The study also carries out water quality test of the raw water of the River and compares this with local and international standards to identify the level of purification needed for portable water supply. Finally, it analyses the temporal dimension of water abstraction and supply from the Isashi water intake and synthesizes the findings for planning and developmental purposes of the catchment.

\section{Materials and Methods}

\subsection{Study Area}

The Owo River Catchment is located in the Ogun River Basin in South Western Nigeria. The catchment is located in the western part of Lagos state, and parts of Ogun state. Ishasi waterworks which supplies water to Amuwo-Odofin, Festac, Ojo, Satellite Town, Ijanikin and other settlements source its raw water from River Owo. The catchment is located between latitudes $6^{\circ} 27^{\prime} 23^{\prime \prime}$ and $6^{\circ} 54^{\prime} 22^{\prime \prime}$ and longitudes $3^{\circ} 16^{\prime} 60^{\prime \prime}$ and $3^{\circ} 4^{\prime} 36^{\prime \prime}$ and covers 12 local government areas, 10 in Lagos state and 2 in the neighbouring Ogun State [10]. The total length of its primary river (Owo River) is $71.15 \mathrm{~km}$. It is a tributary of River Ore and empties into the Ologe Lagoon. River Owo has a safe yield of 28 million gallons per day [MGD] (127.1 million litres per day [MLD]), which translates to a monthly average of about 840 MGD (3813 MLD) [17] [10]. There are about 156 settlements within the catchment area which covers about $1170.68 \mathrm{~km}^{2}$. Urbanization and industrialization have significantly impacted the dominant agricultural landuse of the catchment area.

The catchment is within the humid tropical climate and has a mean annual rainfall of about $2721 \mathrm{~mm}$. Average annual number of rain days is about 170, mean monthly rainfall is about $229 \mathrm{~mm}$ and mean daily temperature is about $27.8^{\circ} \mathrm{C}$. The catchment falls within geological formation called Ilaro Formation. The formation contains both marine and continental deposits and rocks of sedimentary origin. Vegetal cover is made up of heavy forest, derived forest and intensive riparian forest along the drainage paths. Figure 1 shows the location of Owo River catchment in Lagos and Ogun States.

\subsection{Land Use Land Cover and Morpho-Dynamic Changes}

The topographicsheets (1964 and 1984) that covered the basin were mosaicked, geometrically rectified and geo-referenced to the World Space Coordinate System. The mosaicked sheets were spatially aligned or adjusted to the Landsat image to maintain spatial accuracy. The land use classification scheme follows the

Nigerian topographic map sheets. The topographic map sheets (1964) and the ASTER-DEM (30 meters) were used to delineate the watershed area using Arc 


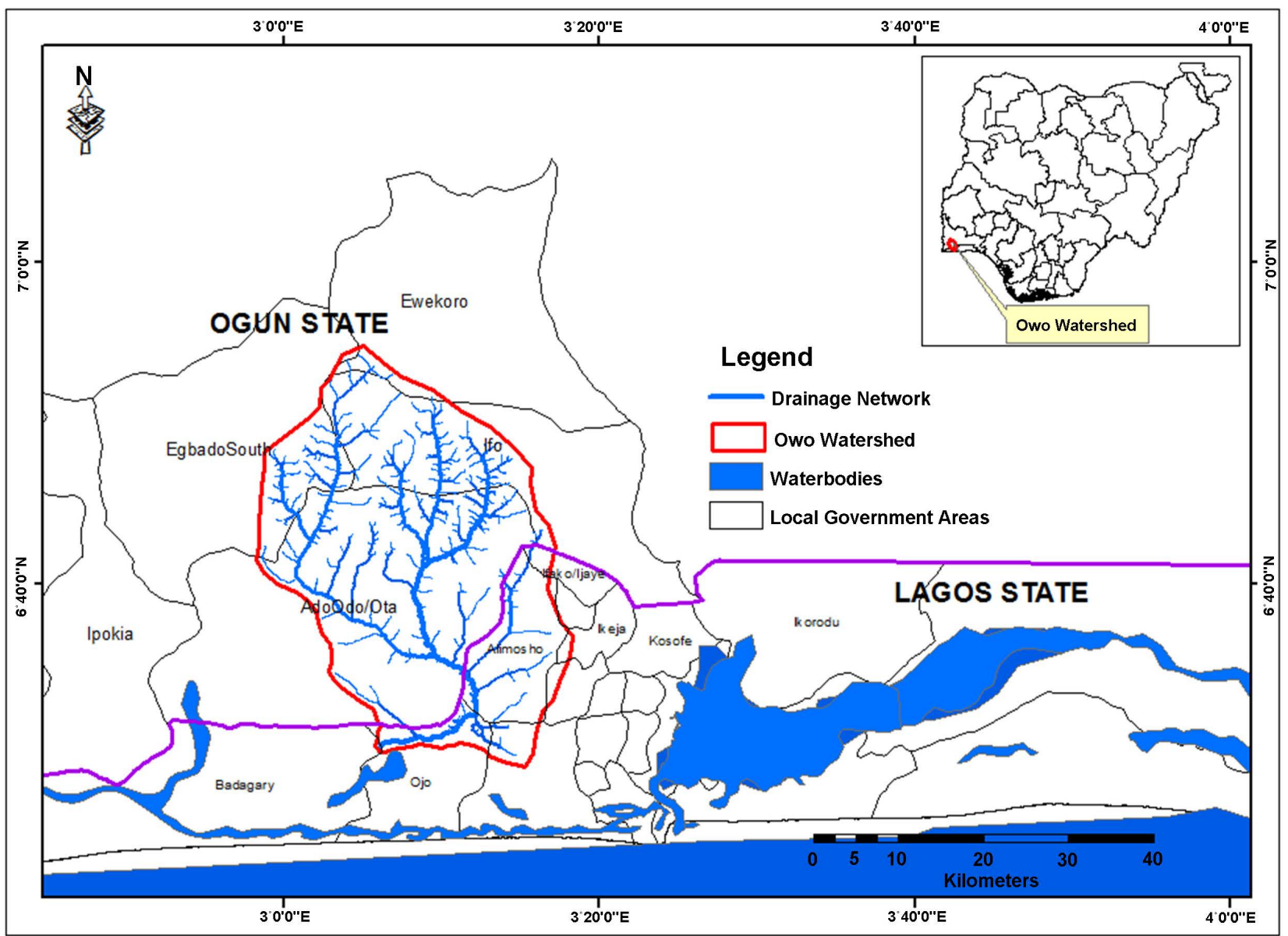

Figure 1. Owo River catchment.

SWAT terrain processing of ASTER-DEM manipulation. The topographic map sheets for 1984, LANDSAT ETM (Enhanced TM-7, 4, 2 bands) and LANDSAT 8 (OLI-5, 3, 2 bands) were used to map the land use land cover for years 1984, 2000 and 2013 respectively. To generate the land uses using supervised classification method in ENVI, certain numbers of training datasets were randomly sampled from the spectral signature of each of the classes to define their respective landuse/landcover type.

Analyses carried out include static area calculation of the land uses (1984, 2000 and 2013) and change detection using the ENVI overlay analytical tool [10]. On-screen digitization was used to extract the drainage network of Owo catchment from the 1964 mosaicked topographical sheets. The drainage network system for 2010 was extracted from the ASTER-DEM through terrain preprocessing manipulations in the ArcHydro extension of Arc GIS 10.3. Other analysis includes, Fill sink, Flow Accumulation, Stream Definition and Stream Segmentation using the D-8 drainage extraction model algorithm to define the landscape properties for each individual raster cell by the evaluation of each cell and its eight (8) neighbours [7]. Morphometric variables including bifurcation ratio, drainage density, stream frequency, drainage intensity and stream length 
were spatio-temporally examined by comparing the results from the topographical map sheets and the results from ASTER-DEM.

\subsection{Rainfall Modelling and Forecasting}

The modelling and forecasting of the time series of rainfall of the catchment was carried out using the Autoregressive Integrated Moving Average (ARIMA) model. The ARIMA modelling was carried out in XLSTAT based on the Box-Jenkins approach. The ARIMA model is generally expressed as:

$$
\begin{gathered}
U_{t}=\varnothing_{1} U_{t-1}+\varnothing_{2} U_{t-2}+\cdots+\varnothing_{p} U_{t-p}+\varepsilon_{t}-\theta_{1} \varepsilon_{t-1}-\theta_{2} \varepsilon_{t-2}-\cdots-\theta_{q} \varepsilon_{t-q} \\
U_{t}=X_{t}-X_{t-d}
\end{gathered}
$$

where, $\varnothing_{p}$ is the autoregressive parameter, $\varepsilon_{t}$ is the residual, $\theta_{q}$ is the moving average parameter, and $X$ is the dependent variable.

The rainfall modelling was achieved based on the following steps:

1) Confirmation of Non-Stationary;

2) Plotting of the Autocorrelation Function (PACF) and Partial Autocorrelation Function (PACF) of the Annual Rainfall Series: In the computation of the autocovariance function [ck] (Equation (3)), the autocorrelation coefficient [rk] (Equation (4)), the partial correlation function $([\varnothing(k)])$ (Equation (5)) and the plots of the ACF and PACF were used to determine the general characteristics, and the stationarity or non-stationarity of the time series.

$$
\begin{gathered}
c_{k}=\frac{1}{N} \sum_{t=1}^{N-K}\left(x_{t}-\bar{x}\right)\left(x_{t+k}-\bar{x}\right), \quad 0 \leq k \leq N \\
r_{k}=\frac{c_{k}}{c_{0}}=\frac{\sum_{t-1}^{N-K}\left(x_{t}-\bar{x}\right)\left(x_{t+k}-\bar{x}\right)}{\sum_{t-1}^{N}\left(x_{t}-\bar{x}\right)^{2}} \\
\hat{\emptyset}_{k+1}(k+1)=\left[r_{k+1}-\sum_{j=1}^{k} \hat{\varnothing}_{k}(j) r_{k+1-j}\right] /\left[1 \sum_{j=1}^{k} \hat{\emptyset}_{k}(j) r_{j}\right]
\end{gathered}
$$

where, $\varnothing_{p}$ is the autoregressive parameter, $\varepsilon_{t}$ is the residual, $\theta_{q}$ is the moving average parameter, $X$ is the dependent variable, and $U$ is the dth difference of the dependent variable.

Trend and Stationarity Tests: A number of tests were deployed to determine the presence or absence of trend, and the presence or absence of stationarity. The Mann-Kendall trend test (Equations (6) and (7)) was used to test for trend. The Stationarity of the rainfall time series was determined using the Augmented Dickey-Fuller [ADF] test (Equation (8)), a unit root approach commonly used to determine the stationarity or non-stationarity of a time series [18] [19] [20] [21].

Test Statistic

$$
Z_{c}\left\{\begin{array}{l}
\frac{S-1}{\sqrt{\operatorname{var}(S)}}, S>0 \\
0 S=0 \\
\frac{S+1}{\sqrt{ } v 7 \operatorname{ar}(S)}, \quad S<0
\end{array}\right.
$$




$$
S=\sum_{i=1}^{n-1} \sum_{k=i+1}^{n} \operatorname{sgn}\left(x_{k}-x_{i}\right)
$$

where $x_{k}$ and $x_{\mathrm{j}}$ are the sequential data values, $n$ is the length data set, and sgn $(\theta)$ is equal to $1,0,-1$ if $\theta$ is greater than, equal to, or less than zero, respectively.

Augmented Dickey-Fuller [ADF] test

$$
\nabla_{x t}=\theta_{0}+\beta_{t}+\Phi x_{t-1} \theta_{1} \nabla x_{t-1}+\cdots+\theta_{p} \nabla x_{t-p}+w_{t}
$$

where, $\nabla x_{t}$ is the first differenced value $\left(x_{t}\right), w_{t}$ is the error term, $X_{t-1}$ is the first lagged value of the series $\left(x_{t}\right), \nabla x_{t-j}$ is the $j$ th lagged first differenced of values of $x_{t}, \theta_{0}, \beta, \Phi=\varnothing_{-1}, \theta_{1}, \theta_{2}, \cdots \theta_{p}$ are estimated parameters.

1) Differencing: The stationarity of the annual rainfall time series was achieved through differencing. The series was differenced once $(d=1)$, and twice $(d=2)$. Their ACFs and PACFs were also plotted and analysed. This was done to ensure that there was no under-differencing or over-differencing of the series. A rapidly decaying ACF and PACF is an indication of the attainment of stationarity, while a lag $1 \mathrm{ACF}$ and PACF lesser than -0.5 is an indication of an over-differenced time series (Huang et al., 2016). The standard deviations of $d=$ 1 and $d=2$ were also compared to establish the optimum differenced series;

2) Identification of the Order of Autoregressive and Moving Average Parameters and Choice of Best ARIMA Model: The autoregressive (AR)p and the Moving Average (MA)q parameters of the ARIMA model were determined from the once differenced $(d=1)$ series, which was established as the optimum differenced series. Different values of $\mathrm{p}$ and $\mathrm{q}$, up to a maximum value of 3 were tried and fitted into the model to select the best model. The ARIMA models (110), (111), (112), (113), (210), (211), (212), (213), (310), (311), (312), and (313) were tested. In ensuring that the model with the least complexity and greatest explanatory power was selected, the Akaike Information Criteria was used to test the different $\mathrm{p}$ and $\mathrm{q}$ values. The model with the minimum AICC was chosen as the best model and diagnostic tests were conducted to confirm the model's validity;

3) Diagnostic Testing: The diagnostic tests involved testing the residual values for independence by inspecting the ACF and PACF plots of the residuals. The Breusch-Pagan Test was used to confirm the residuals' homoscedasticity, while the Jarque-Bera test, the Shapiro-wilk test, the Anderson-Darling test and the Lilliefors test were used to confirm the normality of the residuals' distribution;

4) Series Comparison and Forecasting: The synthetic and the observed rainfall series were compared to determine the level of their similarity, while forecast values for 4 years between 2012 and 2015 were also generated. The relative error (Equation (9)) was used to estimate the extent of difference between the forecasted and the observed annual rainfall as follows:

$$
\operatorname{ERR}(\%)=\sum_{i=1}^{n} X_{\text {For }}-\sum_{i=0}^{n} X_{\text {Obs }} * 100
$$

where,

$X_{\text {for }}=$ forecasted annual rainfall;

$X_{o b s}=$ observed annual rainfall. 


\subsection{Water Quality, Abstraction and Supply}

The laboratory experimental technique was used to analyze the quality of the surface water from three sample points along the Owo River course (upper, middle and lower sections). Surface water samples were collected at about $0.5 \mathrm{~m}$ depth in acid clean 2-L plastic bottles with screw caps [22] [23]. In order to minimized the absorption of metals onto the sample bottles wall, the water samples were acidified using nitric acid [23] [24] [25] and immediately transferred to a cool storage environment at $-10^{\circ} \mathrm{C}$ so as to retain the physical properties of the water samples. Hydrogen ion concentration $(\mathrm{pH})$, conductivity/salinity, turbidity, dissolved oxygen and temperature of samples were measured in-situ using a Metrohm Herisau E520 pH meter, HACH-Hq 40d multi-parameter, a Nephelometer (Analite portable nephelometer Model 156, Mcvan Instrument, Mulgrave). Jenway dissolved oxygen meter and a mercury-in-glass thermometer, respectively.

The variables determined include; total suspended solids (TSS), total dissolved solids (TDS), total solids (TS), dissolved oxygen (DO), chemical oxygen demand (COD), biological oxygen demand (BOD), acidity and alkalinity. These were done using American Public Health Association method [23] [24]). Also, the nutrient and metal analyses followed the methodology described in [23]. The nutrients including, phosphate, nitrate and sulphate were spectrophotometrically determined from digest samples while the metals were determined by aspiration of samples into the flames of an Atomic Absorption Spectrophotometer (Alpha-4 cathodeon). In addition to the surface water quality analysis to determine the level of pollution from anthropogenic activities, water abstraction and supply data from Owo River at Ishasi waterworks between years 2004-2011 were collected from the Lagos State Water Corporation (LSWC) and examined for temporal variability using F-test or Fisher distribution and the coefficient of variation $(\mathrm{CV})$.The details of all the sources and characteristics of all the data used for the study is as presented in Table 1.

The results of land use and morpho-dynamics, rainfall stationarity, water quality and water abstraction were synthesized to explain the current trend in human and natural processes that are shaping the human environment nexus in the Owo catchment, particularly as it affects the sustainable urban water supply, sustained urban growth and climate change related issues.

\section{Results and Discussion}

\subsection{Landuse Change Analysis}

Table 2 shows the static land uses for 1984, 2000 and 2013. Built-up area remains the dominant landuse with a progressive landuse change that increased from $12.20 \%$ in 1984 to $20.69 \%$ and $31.36 \%$ in 2000 and 2013 respectively [10]. The pattern of changes is shown in Figure 2 and Figure 3. The increasing human activities as shown in the changes have the potential to increase surface water pollution in the area. Forested land covers play a major role in reducing the 
Table 1. Sources and characteristics of data used for the study.

\begin{tabular}{|c|c|c|c|c|}
\hline Data & Year & Instrument & Resolution & Source \\
\hline LANDSAT TM & 1984 & $\begin{array}{c}\text { Thematic Mapper } 7 \text {, } \\
4,2 \text { bands }\end{array}$ & 30 meters & USGS, glovis.org \\
\hline LANDSAT ETM & 2000 & $\begin{array}{c}\text { Thematic Mapper } 7 \\
\text { 4, } 2 \text { bands }\end{array}$ & 30 meters & USGS, glovis.org \\
\hline LANDSAT 8 & 2013 & OLI-5.3, 2 bands & 30 meters & USGS, glovis.org \\
\hline Topographic Map & 1964 & $\begin{array}{l}279 \text { NW, SW, } \\
\text { NE, NW }\end{array}$ & $1: 50,000$ & Federal Survey \\
\hline Topographic Map & 1984 & $\begin{array}{c}279 \mathrm{NW}(1,2,3,4) \\
\mathrm{SW}(1,2,3,4), \mathrm{NE} \\
(1,2,3,4), \mathrm{NW} \\
(1,2,3,4)\end{array}$ & & Lagos State Survey \\
\hline ASTER-DEM & 2010 & $\begin{array}{l}\text { NO6E002, } \\
\text { NO6E003 }\end{array}$ & 30 meters & $\begin{array}{c}\text { USGS, } \\
\text { earthexplorer.org }\end{array}$ \\
\hline $\begin{array}{c}\text { Rainfall (Abeokuta } \\
\text { and Lagos }\end{array}$ & $1981-2011$ & & Yearly & $\begin{array}{c}\text { National Bureau } \\
\text { of Statistics }\end{array}$ \\
\hline $\begin{array}{l}\text { Water Abstraction } \\
\text { and Supply }\end{array}$ & 2004-2011 & & Monthly & $\begin{array}{c}\text { Lagos State Water } \\
\text { Corporation }\end{array}$ \\
\hline
\end{tabular}

Table 2. Landuse dynamics of Owo River Basin in 1984, 2000 and 2013.

\begin{tabular}{crrrrrr}
\hline & \multicolumn{2}{c}{ Landuse in 1984} & \multicolumn{2}{c}{ Landuse in 2000} & \multicolumn{2}{c}{ Landuse in 2013} \\
\hline & Area $\left(\mathrm{km}^{2}\right)$ & $\begin{array}{c}\text { \% of } \\
\text { Landuse }\end{array}$ & Area $\left(\mathrm{km}^{2}\right)$ & $\begin{array}{c}\text { \% of } \\
\text { Landuse }\end{array}$ & Area $\left(\mathrm{km}^{2}\right)$ & $\begin{array}{c}\% \text { of } \\
\text { Landuse }\end{array}$ \\
\hline Built-Up Area & 142.92 & 12.20 & 242.33 & 20.69 & 367.22 & 31.36 \\
Heavy Forest & 331.79 & 28.34 & 298.38 & 25.48 & 259.61 & 22.17 \\
Waterbodies & 162.38 & 13.87 & 143.47 & 12.25 & 98.63 & 8.42 \\
Light Forest & 292.43 & 24.97 & 285.27 & 24.36 & 261.33 & 22.32 \\
Riparian & 155.12 & 13.25 & 133.79 & 11.42 & 122.47 & 10.46 \\
Bare Surface & 12.03 & 1.02 & 67.44 & 5.76 & 61.42 & 5.24 \\
Cloud Cover & 74.01 & 6.32 & - & - & - & - \\
Total & 1170.68 & 100 & 1170.68 & 100 & 1170.68 & 100 \\
\hline
\end{tabular}

pollutant load of surface water within their watershed. This is achieved by some special plants that have the ability to digest pollutants or trap pollutants by their fibers from flowing water. Plants also stabilize soil to reduce the rate of sediment runoff, as well as reduce the anthropogenic activities in the watershed [26]. Consequently, the continuous increase in the built-up area poses a big challenge not only to the water supply chain through Ishasi water intake but also to other ecosystem services of the Owo River catchment.

Table 3 and Table 4 describe the change matrix; the diagonal figures highlighted in bold represent the percentage of landuse/landcover classes that have remained in the same locations (area of stability) [9] [10] while other matrices indicate the change to the principal land use [10]. 


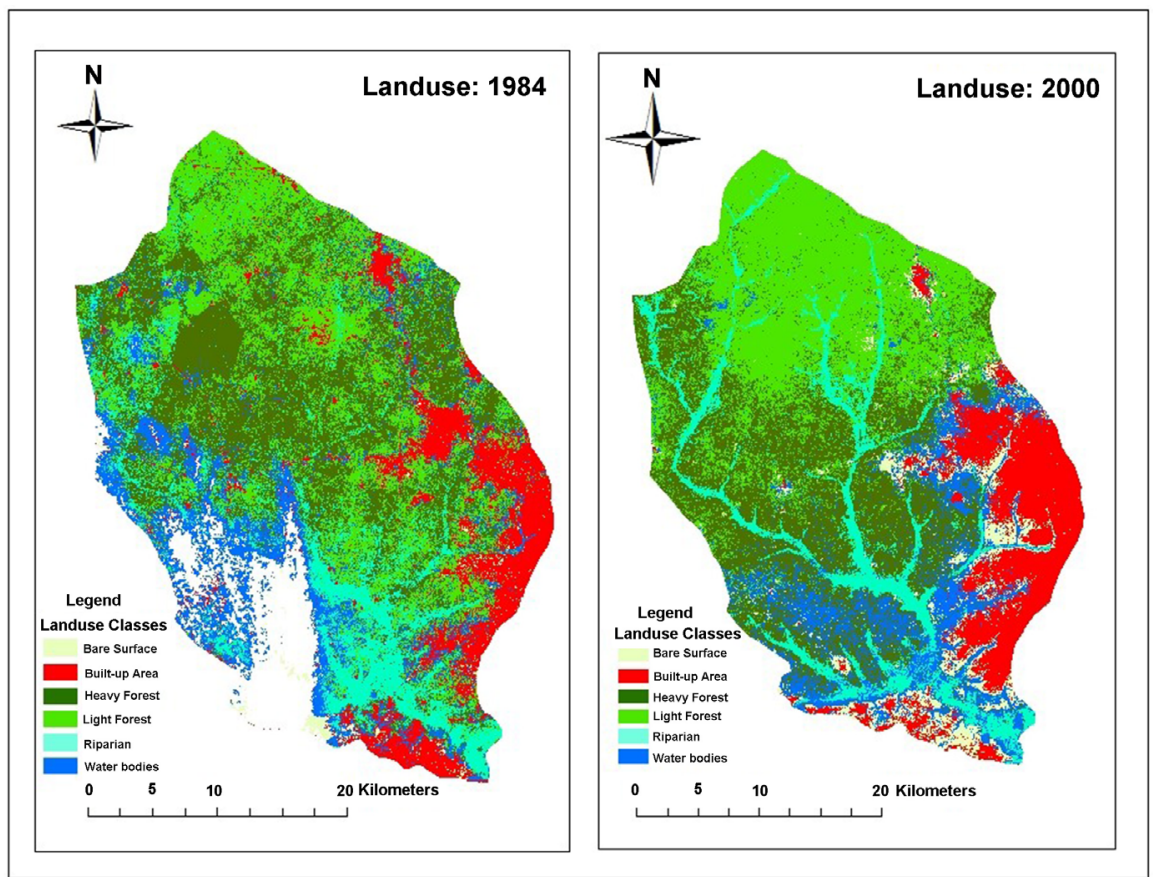

Figure 2. Landuse dynamics of Owo River Basin between 1984 and 200.

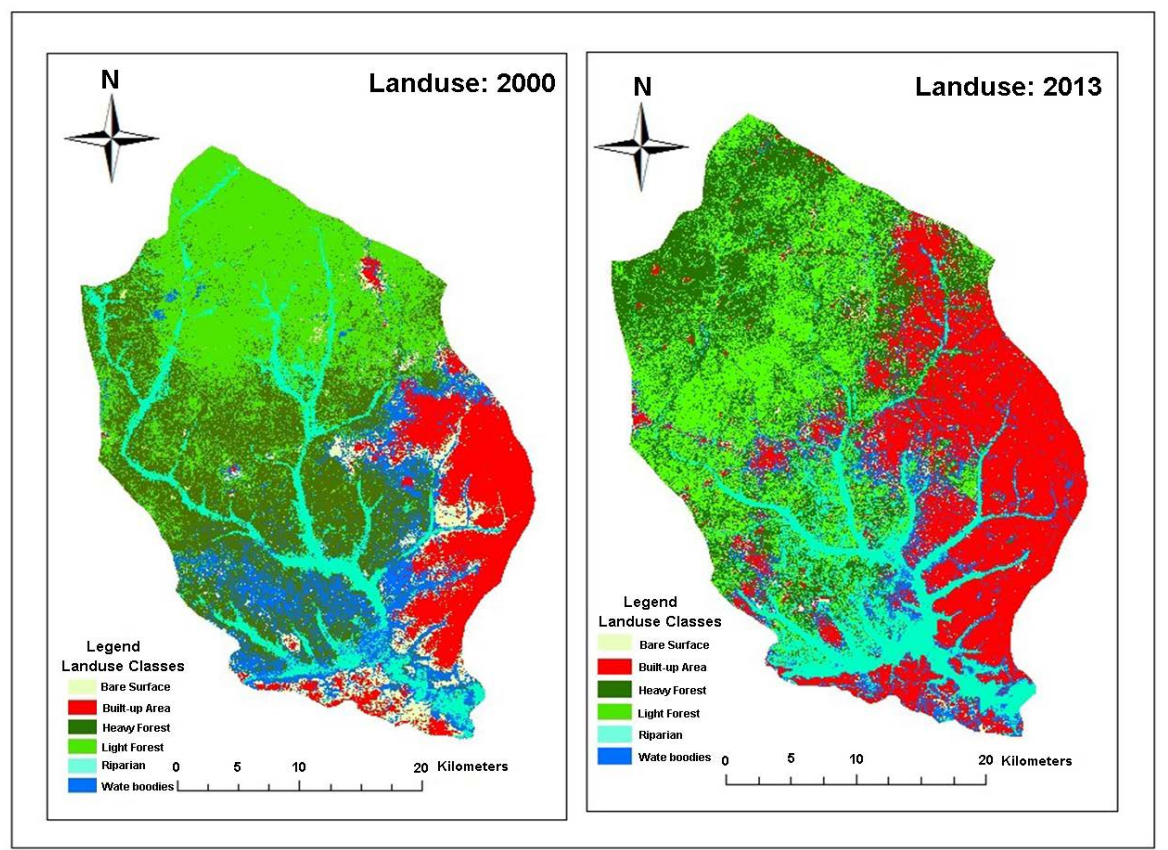

Figure 3. Landuse dynamics of Owo River Basin between 2000 and 2013.

\subsection{Morphometry Dynamics}

Owo River catchment morphodynamics between 1964 and 2010 are shown in Table 5 and Table 6 . The catchment is a $4^{\text {th }}$-order river catchment and has a considerable kinetic energy to erode, transport and deposit sediments [10].

The morphometric properties of this catchment shows a reduction in the numbers of first and second order streams in 2010 when compared with the 
Table 3. Change detection matrix between 1984 and 2000.

\begin{tabular}{ccccccc}
\hline \multicolumn{7}{c}{ Percentages } \\
\hline & Built-Up & $\begin{array}{c}\text { Heavy } \\
\text { Forest }\end{array}$ & $\begin{array}{c}\text { Water } \\
\text { Bodies }\end{array}$ & Light Forest & Riparian & $\begin{array}{c}\text { Bare } \\
\text { Surfaces }\end{array}$ \\
\hline Built-Up Area & 11.058 & 2.455 & 9.631 & 9.317 & 0.853 & 41.355 \\
Heavy Forest & 0.716 & 36.662 & 40.852 & 20.623 & 28.981 & 13.945 \\
Waterbodies & 1.233 & 7.293 & 14.764 & 9.24 & 20.825 & 14.767 \\
Light Forest & 1.67 & 38.859 & 19.95 & 50.636 & 11.81 & 4.922 \\
Riparian & 83.107 & 11.525 & 8.039 & 4.354 & 34.6 & 2.104 \\
Bare Surface & 2.216 & 3.206 & 6.764 & 5.829 & 2.864 & 22.906 \\
Class Total & 100 & 100 & 100 & 100 & 100 & 100 \\
Class Changes & 88.942 & 63.338 & 85.236 & 49.364 & 65.333 & 77.094 \\
Image Difference & $\mathbf{8 1 . 8 3}$ & $\mathbf{2 . 2 1 3}$ & $\mathbf{- 1 1 . 6 3 9}$ & $\mathbf{1 8 . 0 1}$ & $\mathbf{5 1 1 . 8 5 2}$ & $\mathbf{4 5 9 . 9 8 7}$ \\
\hline
\end{tabular}

Table 4. Change detection matrix between 2000 and 2013.

\begin{tabular}{ccccccc}
\hline \multicolumn{7}{c}{ Percentages } \\
\hline & Built-Up & $\begin{array}{c}\text { Heavy } \\
\text { Forest }\end{array}$ & $\begin{array}{c}\text { Water } \\
\text { Bodies }\end{array}$ & Light Forest & Riparian & $\begin{array}{c}\text { Bare } \\
\text { Surfaces }\end{array}$ \\
\hline Built-Up & 93.241 & 12.628 & 32.863 & 13.178 & 0.152 & 73.555 \\
Heavy Forest & 0.436 & 30.595 & 12.877 & 42.872 & 3.133 & 2.466 \\
Waterbodies & 4.715 & 10.981 & 16.706 & 3.928 & 0.675 & 16.447 \\
Light Forest & 0.158 & 30.742 & 5.226 & 35.855 & 3.022 & 0.941 \\
Riparian & 0.189 & 12.31 & 29.848 & 1.339 & 7.873 & 1.728 \\
Bare Surface & 1.261 & 2.744 & 2.481 & 2.828 & 85.145 & 4.863 \\
Class Total & 100 & 100 & 100 & 100 & 100 & 100 \\
Class Changes & 6.759 & 69.405 & 83.294 & 64.145 & 92.127 & 95.137 \\
Image Difference & $\mathbf{1 1 5 . 5 5 4}$ & $\mathbf{- 1 2 . 1 3}$ & $\mathbf{- 3 1 . 2 5 3}$ & $\mathbf{- 2 4 . 3 4}$ & $\mathbf{- 8 1 . 0 3 8}$ & $\mathbf{9 7 3 . 4 4 3}$ \\
\hline
\end{tabular}

Table 5. Morphometry dynamics of Owo River Basin.

\begin{tabular}{ccccccc}
\hline \multicolumn{3}{c}{ River: 1964} & \multicolumn{5}{c}{ River: 2010} \\
\hline Stream Order & Number & Length & Bifurcation & Number & Length & Bifurcation \\
\hline 1 & 218 & 322.71 & 2.20 & 160 & 297.97 & 1.95 \\
2 & 99 & 158.56 & 1.34 & 82 & 149.45 & 2.83 \\
3 & 74 & 92.33 & 2.18 & 29 & 51.36 & 1.45 \\
4 & 34 & 48.64 & - & 20 & 57.20 & - \\
Total 425 & 622.24 & & 291 & & 555.98 \\
\hline
\end{tabular}

Table 6. Changes in other morphometric indices of Owo River Basin.

\begin{tabular}{ccc}
\hline Morphometric Variables & River: 1964 & River: 2010 \\
\hline Drainage Density $\left(\mathrm{mi} / \mathrm{mi}^{2}\right)$ & 0.53 & 0.47 \\
Stream Frequency $\left(\mathrm{mi} / \mathrm{mi}^{2}\right)$ & 0.0003 & 0.0002 \\
Drainage Intensity $\left(\mathrm{mi} / \mathrm{mi}^{2}\right)$ & 0.00056 & 0.00042 \\
\hline
\end{tabular}


numbers in 1964. Variables that have reduced include the numbers of streams, stream length and bifurcation ratio [10]. Many of the first-order stream channels are no longer in existence owing to anthropogenic activities that have buit-up these sub-catchments and rendered there channels to mear street drainage. This situation has serious implications on the water yield both in terms of quantity and quality within the catchment. Table 6 and Figure 4 show the changes in the morphometric indices and morpho-dynamics of the Owo River Basin drainage network between 1964 and 2010 .

\subsection{Rainfall Modelling and Forecasting}

1) Rainfall Non-Stationarity: The summary of the results of the trend and stationarity tests are represented in Table 7. The result of the Mann-Kendall trend test showed that the computed p-value is lower than the significance level ( $\alpha=$ 0.05 ), so the null hypothesis of no trend was rejected, while the alternative hypothesis of the presence of trend was accepted. The existence of trend in the rainfall time series is an indication of non-stationarity in the hydro-climatic time series of the catchment.

For the ADF test the null hypothesis of the existence of unit root was accepted as the computed $\mathrm{p}$-value was greater than the significance level $(\alpha=0.05)$. A non-stationary time series is one that exhibits either a trend or unit root, and therefore requires differencing to transform it into a stationary time series [21].

2) Differencing and Transformation to Stationary Series: A comparison of the $\mathrm{ACF}$ and PACF of the once differenced series $[d=1]$ (Figure 5 and Figure 6) with the ACF and PACF of the twice differenced series $[d=2]$ (Figure 7 and Figure 8), showed that the ACF and PACF of the once differenced series

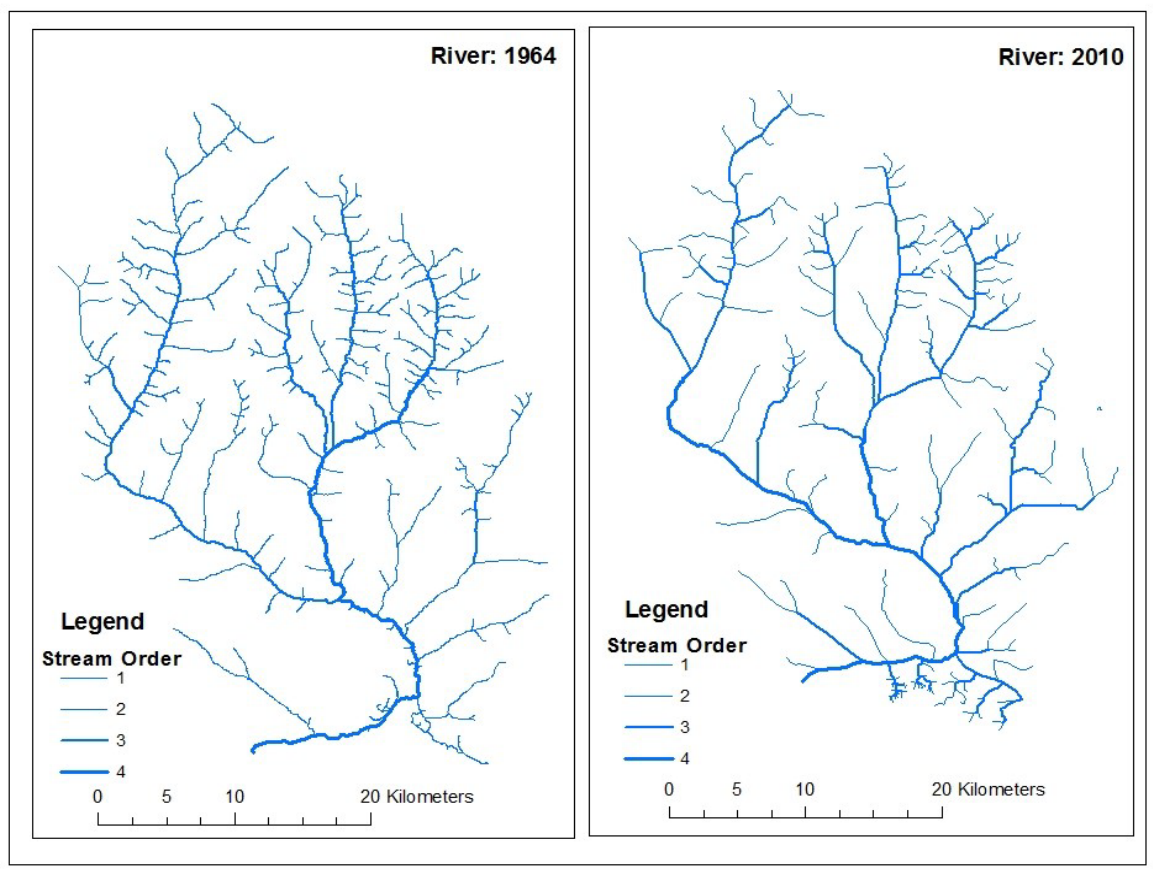

Figure 4. Morphodynamic characteristics of Owo River Basin between 1964 and 2010. 


\section{Autocorrelogram (Series1)}

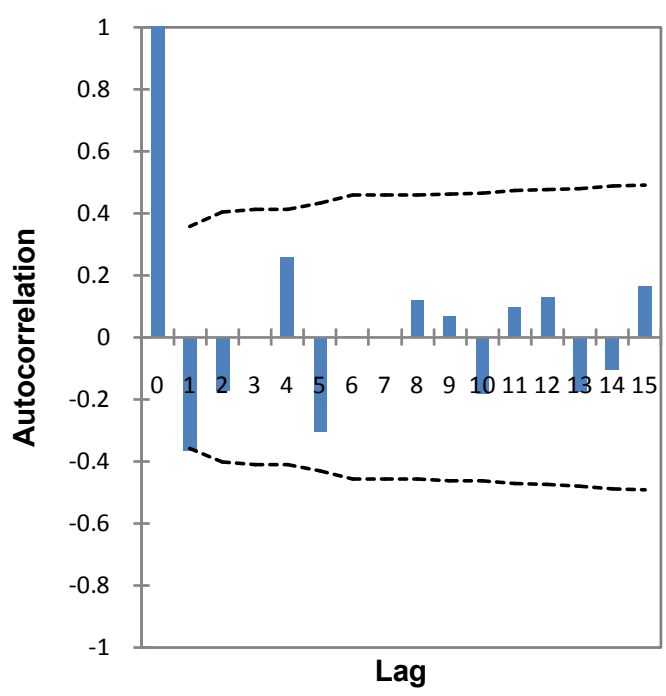

Figure 5. ACF of once differenced series.

Partial autocorrelogram (Series1)

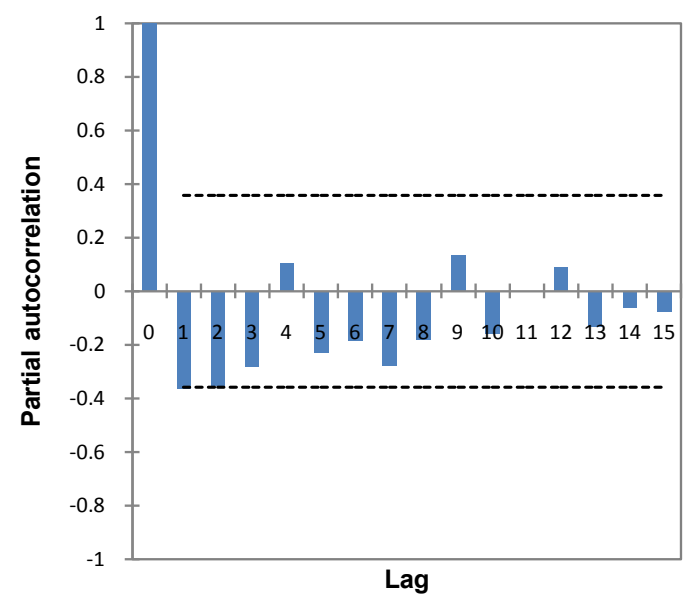

Figure 6. PACF of once differenced series.

Autocorrelogram (Series1)

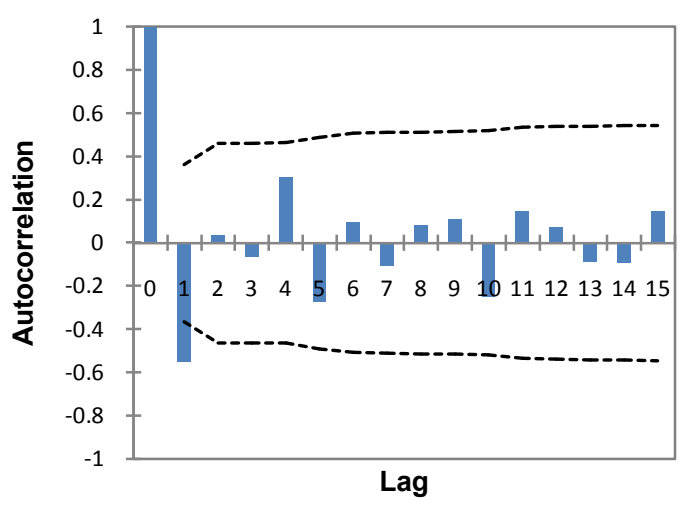

Figure 7. ACF of twice differenced series. 
Partial autocorrelogram (Series1)

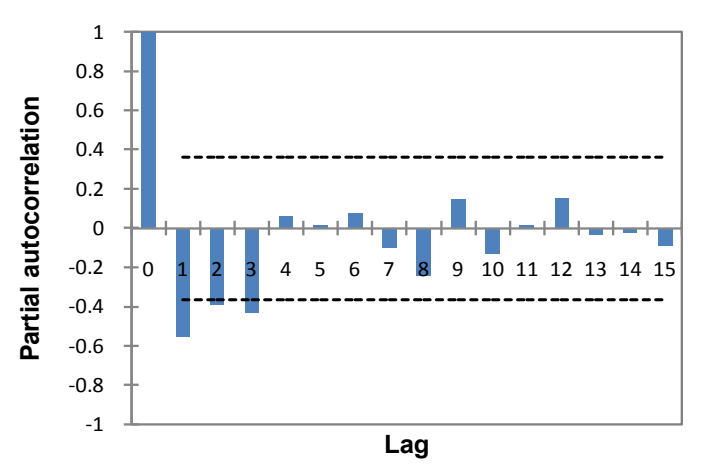

Figure 8. PACF of twice differenced series.

Table 7. Trend and stationarity tests.

\begin{tabular}{ccc}
\hline Test & p-Value & Remark \\
\hline MK & $\mathbf{0 . 0 2 2}$ & Trend, Non-Stationary \\
ADF & 0.241 & Unit Root, Non-Stationary \\
\hline
\end{tabular}

decayed more rapidly. The comparison of standard deviation of $d=1$ (301.37) with the standard deviation of $d=2$ (495.04), showed that the once differenced series has the lower value. Also, a scrutiny of the ACF and PACF plots showed that the first lags of the twice differenced series $(d=2)$ were lesser than -0.5 , indicating over-differencing. These comparisons therefore qualified $d=1$, as the optimum level of differencing, thus, the $d$ value of 1 was used for the modelling. The ACF and PACF plots (Figures 5-8) for the rainfall series showed a slow decay suggesting that the rainfall time series may be non-stationary.

3) ARIMA Modelling and Diagnostic Testing: Among the various models tested, ARIMA model 110 (Table 8) had the lowest AICC value and was therefore chosen as the best model. The ACF and PACF plots of the model residuals' fell within the confidence interval, indicating independence. The result of Breusch-Pagan test for the determination of the residuals' homoscedasticity (Table 9) showed that the residuals were homoscedastic. Homoscedasticity of residuals' is an indication of a model's consistency and ability to predict variable values (Huang et al., 2016). The null hypothesis for all the tests of normality (Table 10) was accepted, indicating that the model's residuals were normally distributed.

4) Series Comparison and Forecasting: Figure 9 is a comparison of the observed and synthetic rainfall series of ARIMA model (110). As is evident from the figure, the synthetic rainfall series exhibited a pattern similar to the pattern of the observed rainfall series. The observed and forecasted annual rainfall for years 2012 to 2015 are presented in Table 10.

The estimated relative error between the forecasted and the observed annual rainfall for the time period was 4 percent, indicating a relatively small difference between forecasted and the observed. 
Table 8. Result of ARIMA 110 Model.

\begin{tabular}{ll}
\hline Variable & Value \\
\hline AICC & 426.39 \\
MAPE & 17.97 \\
AR (1) & $\mathbf{0 . 4 0}$ \\
\hline
\end{tabular}

Table 9. Results of homoscedasticity and normality test.

\begin{tabular}{lccccc}
\hline $\begin{array}{l}\text { Homoscedasticity } \\
\text { Test }\end{array}$ & \multicolumn{5}{c}{ Normality Test } \\
\hline Breusch-Pagan Test & Shapiro-Wilk Test & Anderson-Darling Test & Lilliefors Test & Jarque-Bera Test \\
\hline p-Value & 0.052 & 0.72 & 0.62 & 0.5 & 0.67 \\
$\alpha$-Value & 0.05 & 0.05 & 0.05 & 0.05 & 0.05 \\
\hline
\end{tabular}

Table 10. Observed and forecasted annual rainfall from 2012 to 2015.

\begin{tabular}{ccc}
\hline Year & Observed Rainfall & Forecasted Rainfa \\
\hline 2012 & 1460.6 & 1525.6 \\
2013 & 1283.8 & 1519.1 \\
2014 & 1830.1 & 1521.6 \\
2015 & 1265.7 & 1520.6 \\
\hline
\end{tabular}
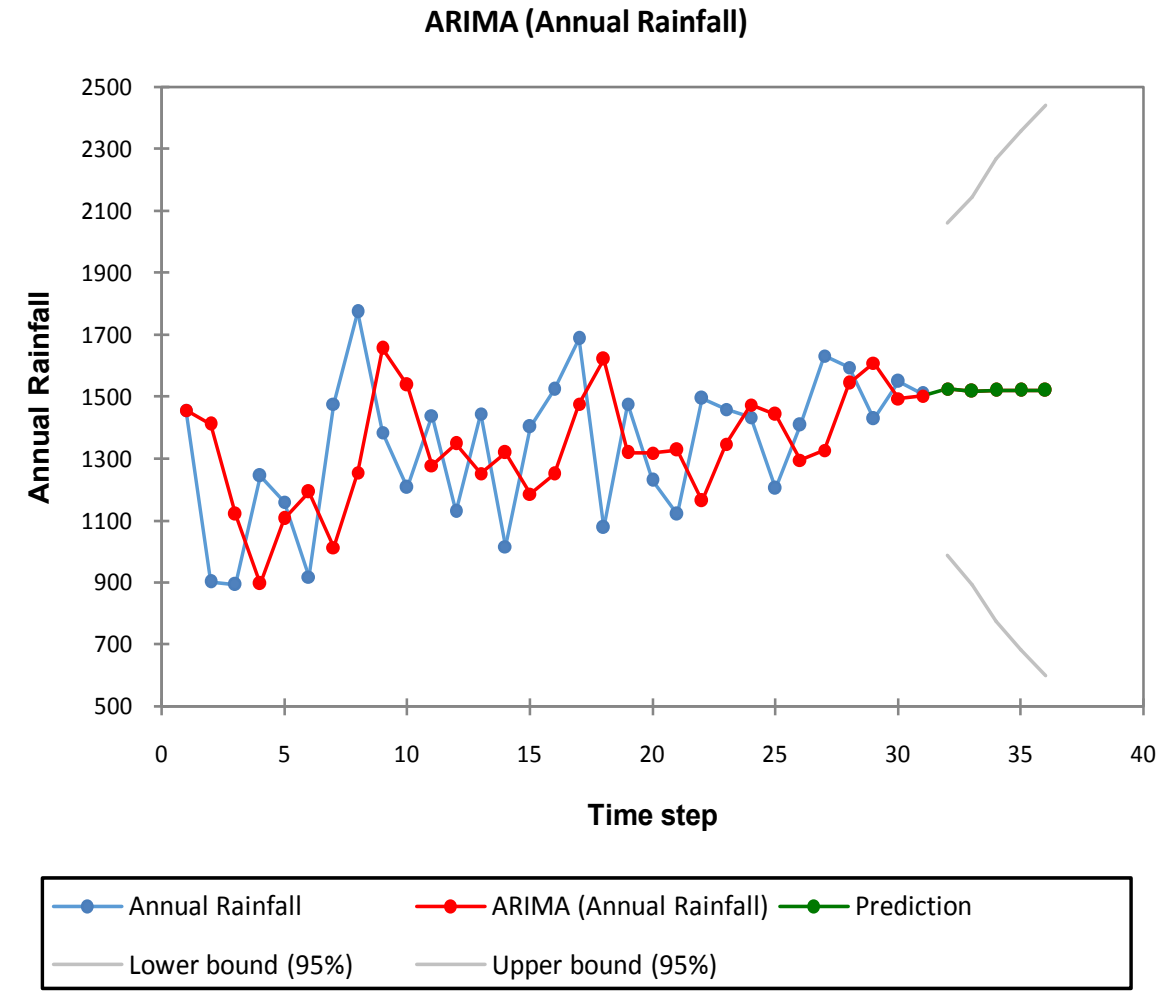

Figure 9. Comparison of observed and synthetic rainfall series of ARIMA model (110). 


\subsection{Water Quality}

There are no stipulated standards for hardness, acidity, alkalinity, Total Suspended Solids, Total Solids, Dissolved Oxygen, Biochemical Oxygen Demand, Chemical Oxygen Demand, and Phosphate (Table 11). Conductivity and hardness, however, have national stipulated standards of $1000 \mu \mathrm{S} / \mathrm{cm}$ and $150 \mathrm{mg} / \mathrm{L}$. Thus, the sampled water from the three locations had values below these standards. PH, Chloride, Total Dissolved Solids (TDS) and Nitrate which have stipulated standards, all had concentrations within and below these standards.

As revealed by the results of the laboratory analysis, the level of electrical conductivity of the river is generally low, and this is also reflected in the low concentration of the TDS in the water. As explained by [27], electrical conductivity is a good indicator of TDS concentration in water. With regards to taste and palatability of water, the raw water of the river falls within the fair taste category. According to [28] water with TDS concentration in the range of $300-600$ $\mathrm{mg} / \mathrm{L}$ falls within the fairly palatable taste category. The level of hardness of the water is below the national standard of $150 \mathrm{mg} / \mathrm{L}$. In the upper reaches of the river, the water can be classified as soft water. Water with a hardness concentration of less than $60 \mathrm{mg} / \mathrm{L}$ are generally categorized as soft and have a greater potential for corroding Copper and Lead pipes in a water distribution system than hard water [29].

With regards to the clarity or turbidity of the water, the concentration of Total Suspended Solids in the middle section of the river was higher than the concentrations at the upper and low reaches, indicating a greater turbidity level. The higher the concentration of suspended solids in a water body, the more turbid it is [30].

Other chemical analyses show that the Owo River has a significant level of pollutant loading as indicated by the concentrations of Chloride, Chemical Oxygen Demand (COD) and Biological Oxygen Demand (BOD). Likely anthropogenic sources of these pollutants identified within the catchment include urination and defecation in the waters, discharge of sewage, and oil and grease spillage from ferries that ply the river as well as those from the mechanic workshops along the river bank flood. As shown in Table 11, the COD and BOD levels of the water are significantly higher than those normally encountered in unpolluted waters. As observed by [31], concentrations of COD and BOD in unpolluted waters is normally around $20 \mathrm{mg} / \mathrm{L}$ and $2 \mathrm{mg} / \mathrm{L}$ respectively. With a sustained increase in the anthropogenic activities and built environment within the watershed, the likelihood of an increase in the pollutants is high. This become even more worrisome when considered in the direction of change that is being experienced within the catchment, which is noted in the continuous loss in vegetation cover that naturally the provide ecosystem service of water purification.

For the raw water to meet an acceptable standard for drinking water, the abstracted water is subjected to five treatment processes before being stored or 
Table 11. Chemical properties of Owo River in comparison with WHO limit.

\begin{tabular}{ccccccc}
\hline Parameter & $\begin{array}{c}\text { Upper } \\
\text { Section }\end{array}$ & $\begin{array}{c}\text { Middle } \\
\text { Section }\end{array}$ & $\begin{array}{c}\text { Lower } \\
\text { Section }\end{array}$ & Mean & $\begin{array}{c}\text { WHO } \\
\text { Standard }\end{array}$ & $\begin{array}{c}\text { NSDQW } \\
\text { Standard }\end{array}$ \\
\hline $\mathrm{pH}$ & 7.21 & 7.66 & 7.58 & 7.5 & $6.5-8.5$ & $6.5-8.5$ \\
Conductivity $\mu \mathrm{S} / \mathrm{cm}$ & 640 & 445 & 601 & 562 & NA & 1,000 \\
Chloride mg/L & 131 & 157 & 210 & 166 & 250 & 250 \\
Hardness mg/L & 45 & 93.7 & 132.6 & 90.4 & NA & 150 \\
Acidity mg/L & 1.8 & 2.7 & 9.9 & 4.8 & NA & NA \\
Alkalinity mg/L & 23.0 & 61.3 & 91.9 & 58.7 & NA & NA \\
Total Suspended Solids mg/L & 40.0 & 70.0 & 50 & 53.3 & NA & NA \\
Total Dissolved Solids mg/L & 330 & 230 & 310 & 290 & 1000 & 500 \\
Total Solids mg/L & 370 & 300 & 360 & 343.3 & NA & NA \\
Dissolved Oxygen mg/L & 9.58 & 1.69 & 0.68 & 4.0 & NA & NA \\
Biochemical Oxygen Demand & 38.6 & 22.4 & 37.2 & 33.1 & NA & NA \\
mg/L & 70.1 & 43.8 & 61.3 & 58.4 & NA & NA \\
Chemical Oxygen Demand mg/L & 10.56 & 1.53 & 4.26 & 5.5 & 50 & 50 \\
Nitrate mg/L & 0.26 & 0.12 & $\mathbf{0 . 1 3}$ & $\mathbf{0 . 2}$ & NA & NA \\
Phosphate mg/L & & & & & &
\end{tabular}

Source: Laboratory Analysis, 2017. NA: Not available.

discharged into the distribution network. These processes are coagulation and flocculation, sedimentation, filtration (sand and carbon), disinfection and $\mathrm{pH}$ correction [30]. With regards to the cost of raw water treatment, three factors are largely responsible. First is the quality or the degree of deterioration of the water, second is, the level of treatment required and the degree of purity desired. The third factor is the volume of water required, with the cost of water per volume decreasing as the capacity of the water treatment plant increases [29]. However, a continuous decline in the area of forested land cover within the Owo River catchment will inadvertently contribute to the cost of raw water treatment for municipal water supply, as natural purification by plants will reduce while the level of pollutant will increase [32] have established a direct relationship between the ratio of forest cover in a watershed and the cost of water treatment, with the approximately 50 percent of the variability of water treatment cost determined by the extent forest area in the watershed.

\subsection{Water Abstraction and Supply}

The volume of raw water abstracted between 2004 and 2011 reach its peak of 2207.7 millionlitres in 2008. A minimum of 392.5 millionlitres was recorded in 2010. Also, the volume supplied between 2004 and 2011 reach its peak of 2051.5 millionlitres in 2008 and recorded its minimum of 392.5 millionlitres in 2010. The average volume of water abstracted per year between 2004 and 2011 was 1437.3 million litres while an average of 1344.1 millionlitres was supplied within the same period [10]. However, F-test shows that no significant difference exists 
in the annual water abstraction $\left(\mathrm{Ft}<\mathrm{F}_{0.05}=1.65<9.3\right)$ and annual water supply $\left(\mathrm{Ft}<\mathrm{F}_{0.05}=1.67<9.3\right)$ at the stated level of significance. The $F_{t}$ test value computed is less than its critical value; hence, the null hypothesis is accepted. It is however, concluded that no significant difference exists in the annual water abstraction as well as water supply at $5 \%$ level of significance [10].

\subsection{Synthesis of the Findings}

The land use and morphometric show a reduction in the morphometric indices brought about by a trajectory of land use that is incremental towards the built-up area while the observed non-stationarity in the annual rainfall of the watershed significantly contributed to the observed water availability in quantitative terms, thus, the sustained water abstraction for municipal purposes. Although the increase in the anthropogenic activities and natural rainfall processes have not had a significant impact on water availability (quantity and quality), the continuous pressure on the land resource for developmental purposes may increase its vulnerability to pollution. It may also increase the cost of raw water treatment, reduce the lag time for rainfall runoff response and crystalise other environmental problems such as flood and erosion that are already manifesting in the downstream section of the catchment. In all, it can be concluded that the human-natural ecosystem interaction within the Owo River Catchment has not at present critically affected water supply from the catchment. However, a continuous loss of vegetation and increase pollution may pose greater challenges in the near future.

\section{Conclusion}

This study shows that the Owo River catchment is a highly dynamic catchment; the land use trajectory reveals an urbanization scenario; morphometric changes show reduction in stream network especially the 1st order streams while rainfall trend shows a non-stationarity in the last four decades. These observed changes, therefore, call for urgent action on sustainable catchment management practices if the catchment is to perform its ecosystem functionality role as water supply source to the teeming population of Ishasi and Festac and their immediate environment. It is recommended that eco-friendly development activities that do not compromise the environmental integrity and sustainable urban water supply [15] be put in place to safe Owo River catchment hydro-morphological processes and pollution integrity.

\section{Conflicts of Interest}

The authors declare no conflicts of interest regarding the publication of this paper.

\section{References}

[1] Koundouri, P. and Kountouris, Y. (2008) Water Management and Development. In: 
Desai, V. and Potter, R.B. Eds., The Companion to Development Studies, 2nd Edition, Hodder Education, London, 309-318.

[2] Coco, G. and Murray, A.B. (2007) Patterns in the Sand: From Forcing templates to self-Organization. Geomorphology, 91, 271-290.

[3] Zierl, B. and Bugmann, H. (2005) Global Change Impacts on Hydrological Processes in Alpine Catchments. Water Resource, 41, 396-408. https://doi.org/10.1029/2004WR003447

[4] Oyebande, L. and Odunuga, S. (2010) Climate Change Impact on Water Resources at the Transboundary Level in West Africa: The Cases of the Senegal, Niger and Volta Basins. Open Hydrology Journal, 4, 163-172. https://doi.org/10.2174/1874378101004010163

[5] Raneesh, K.Y. (2014) Impact of Climate Change on Water Resources. Journal of Earth Science \& Climatic Change, 5, 185.

[6] Agrawal, C.S. (1998) Study of Drainage Pattern through Aerial Data in Navgarh Area of Varanasi District, U.P. Indian Journal Society of Remote Sensing, 26, 169-175. https://doi.org/10.1007/BF02990795

[7] Odunuga, S. and Ajayi, O.S. (2017) Morphometric Changes of Ogun River Basin in South-West Nigeria. Benin Journal of Social Sciences, 23, 1-25.

[8] Odunuga, S. and Oyebande, L. (2007) Change Detection and Hydrological Implications in the Lower Ogun Flood Plain, SW Nigeria. Proceedings of Symposium HS3007 at IUGG, Perugia, 2-13 July 2007, 91-99.

[9] Odunuga, S., Omojola, A. and Oyebande, L. (2011) Urban Landuse Dynamics of System 6c Watershed, Lagos, Nigeria. Lagos Journal of Geo-Information Sciences, 1, 7-18.

[10] Adegun, O., Odunuga, S and Ajayi, O.S. (2015) Climate, Runoff and Landuse Trends in the Owo River Catchment in Nigeria. Proceedings of HSO2 Symposium of the International Association of Hydrological Sciences, Prague, 23 June-2 July 2015, 137-142. https://doi.org/10.5194/piahs-371-137-2015

[11] Ojo, O., Oni, F. and Ogunkunle, O. (2003) Implications of Climatic Variability and Climate Change on Water Resources Availability and Water Resources Management inWest Africa. Proceedings of HSO2 Symposium of the IUGG, Sapporo, 30 June-11 July 2003, 37-47.

[12] Kelly, S.A., Takbiri, Z., Belmont, P. and Foufoula-Georgiou, E. (2017) Human Amplified Changes in Precipitation-Runoff Patterns in Large River Basins of the Midwestern United States. Hydrology and Earth System Sciences, 21, 5065-5088. https://doi.org/10.5194/hess-21-5065-2017

[13] Li, Y. and Zhang, Q. (2013) Human-Environment Interactions in China: Evidence of Landuse Change in Beijing-Tianjin-Hebei Metropolitan Region. Human-Ecology Review, 2, 26-35.

[14] Mahmoud, S.H. and Alazba, A.A. (2015) Hydrological Responses to Landcover Changes and Human Activities in Arid Regions Using Geographic Information System and Remote Sensing. PLoS ONE, 10, e0125805. https://doi.org/10.1371/journal.pone.0125805

[15] Zadbagher, E., Becek, K. and Berberoglu, S. (2018) Modelling Landuse/Landcover Change Using Remote Sensing and Geographic Information Systems: A Case Study of Seyhan Basin, Turkey. Environmental Monitoring Assessment, 190, 494. https://doi.org/10.1007/s10661-018-6877-y

[16] Adhikari, S., Shrestha, S.M., Singh, R., Upadhaya, S. and Stapp, J.R. (2016) Land Use Change at Sub-Watershed Level. Hydrology: Current Research, 7, 256. 
[17] Lagos State Water Corporation (2011) Lagos Water Supply Master Plan (2010-2020), Summary Presentation. Lagos State Water Corporation, Lagos.

[18] Yurekil, K. and Cevik, O. (2005) Detection of Whether the Autocorrelated Meteorological Time Series Have Stationarity by Using Unit Root Approach: The Case of Tokat. Gaziosmanpaşa Üniversitesi Ziraat Fakültesi Dergisi, 22, 45-53.

[19] Wang, W., Van Gelder, P.H. and Vrijling, J.K. (2005) Trend and Stationarity Analysis for Streamflow Processes of Rivers in Western Europe in the $20^{\text {th }}$ Century. Proceedings of the IWA Conference on Water Economics, Statistics and Finance, Rethymo, 8-10 July 2005, 451-461.

[20] Khalili, K., Ahamdi, F., Dinpasloh, Y. and Ahmad, F.F. (2013) Determination of Climate Changes on Streamflow Process in the West of Lake Urima with Use of Trend and Stationarity Analysis. International Journal of Advanced Biological and Medical Research, 1, 1220-1235.

[21] Rahaman, M.J., Syeda, J.A. and Nasser, M. (2013) Time Series Properties of Some Climatic Variables in Dinajpur District. Journal of Environmental Science and Natural Resources, 6, 127-137. https://doi.org/10.3329/jesnr.v6i2.22109

[22] Laxen, D.P.H. and Harrison, R.M. (1981) A Scheme for the Physiological Specification of Trace Metals in Fish Samples. Science of the Total Environment, 19, 59-82. https://doi.org/10.1016/0048-9697(81)90119-4

[23] Agboola, J.I., Ndimele, P.E., Odunuga, S., Akanni, A., Kosemani, B. and Ahove, M.A. (2016) Ecological Health Status of the Lagos Wetland Ecosystem: Implications for Coastal Risk Reduction. Estuarine, Coastal and Shelf Science, 183, 73-81. https://doi.org/10.1016/j.ecss.2016.10.019 http://www.elsevier.com/locate/ecss

[24] American Public Health Association (APHA) (1985) Standard Methods for the Examination of Water and Waste Water. 16th Edition, American Public Health Association, Washington DC.

[25] Ademoroti, C.M.A. (1996) Standard Methods for Water and Effluent Analysis. Foludex Press, Ibadan.

[26] Warziniack, T., Sham, C.H., Morgan, S. and Feferholtz, Y. (2016) Effect of Forest Cover on Drinking Water Treatment Costs. American Water Works Association.

[27] Hayashi, M. (2004) Temperature-Electrical Conductivity Relation of Water for Environmental Monitoring and Geophysical Data Inversion. Environmental Monitoring and Assessment, 96, 119-128. https://doi.org/10.1023/B:EMAS.0000031719.83065.68

[28] World Health Organisation (2003) Total Dissolved Solids in Drinking Water. Background Document for Development of WHO Guidelines for Drinking-Water Quality. WHO, Geneva.

[29] Gray, N.F. (2008) Drinking Water Quality. Cambridge University Press, Cambridge. https://doi.org/10.1017/CBO9780511805387

[30] Global Environment Monitoring System (2008) Water Quality for Ecosystem and Human Health. GEMS, Ontario.

[31] Chapman, D. and Kimstach, V. (1996) Selection of Water Quality Variables. In. Chapman, D., Ed., A Guideline to Use of Biota, Sediments and Water in Environmental Monitoring, E and FN Spon, Cambridge, 59-126. https://doi.org/10.4324/NOE0419216001.ch3

[32] Ernst, C., Gullick, R. and Nixon, K. (2004) Protecting the Source: Conserving Forests to Protect Water. American Water Works Association, 30, 1-7. 